\title{
Analysis of the Spatio-Temporal Dynamics of Landuse/ Landcover Stuctures in the Kaduna Innercore City Region, Nigeria
}

\author{
Ndabula C. ${ }^{1}$, Averik P. D. ${ }^{2}$, Jidauna G.G. ${ }^{1, *}$, Abaje I. ${ }^{1}$, Oyatayo T. K. ${ }^{3}$, E. O Iguisi ${ }^{4}$ \\ ${ }^{1}$ Department of Geography and Regional Planning, faculty of Arts Management and Social Sciences, Federal University Dutsinma, \\ Katsina State, Nigeria \\ ${ }^{2}$ Department of Geography and Environmental Management, University of Port-Harcourt, Rivers State, Nigeria \\ ${ }^{3}$ Department of Geography, College of Natural \& Applied science, Kwararafa University Wukari, Taraba State, Nigeria \\ ${ }^{4}$ Department of Geography, Ahmadu Bello University, Zaria, Kaduna State, Nigeria \\ *Corresponding author: gjidauna@fudutsinma.edu.ng
}

Received May 01, 2013; Revised August 07, 2013; Accepted November 20, 2013

\begin{abstract}
This study in addition to the conventional monitoring and mapping of Landuse/Landcover Changes (LULCC), also has as its major objective to quantitatively analyse the spatio-temporal dynamics of these LULCC structures or patterns using five (5) quantitative indices; Normalized Vegetation Difference Index (NDVI), Landuse/Landcover (LULC) Change Intensity Index $\left(\mathrm{T}_{\mathrm{i}}\right)$, Dynamic Index $\left(\mathrm{K}_{\mathrm{i}}\right)$, Integrated Index $\left(\mathrm{L}_{\mathrm{d}}\right)$, and Rate of Change $\left(\mathrm{A}_{\mathrm{i}}\right)$. These indices critically analyse the extent, rate, as well as the magnitude of change among various LULC in the study area, which provides a basis for comparisons with other places and to better explain the nature of spatio-temporal dynamics of LULC as an Index of land degradation. The NDVI on the one hand allows analysis of these LULCC in terms of change in quantity of vegetation cover or bareness of the land surface, while the other four indices on the other hand expressed the intensity with which the land surface is subjected to human activities. The methodology of RS/GIS was used for LULC mapping and NDVI analysis using multi-temporal satellite data sets. Results showed significant dynamics amongst the various LULC in both space and time with implication of decreasing vegetation cover and increasing bare surfaces and hence land degradation processes. Forest has the highest Change Intensity Index $\left(\mathrm{T}_{\mathrm{i}}\right)$ of $5.75 \%$ followed by Built-up $4.08 \%$, and similarly the highest contribution rates $\left(\mathrm{A}_{\mathrm{i}}\right)$ of 49 and $35 \%$ respectively. Built-up has the highest Dynamic Index $\left(\mathrm{K}_{\mathrm{i}}\right)$ of $2.29 \%$ followed by Floodplain Agricultural area $1.92 \%$. Statistical analysis using different regression models as found applicable was performed to observe the trend in LULC change patterns.
\end{abstract}

Keywords: analysis, Landuse/Landcover, spatio-temporal, indices, structures

Cite This Article: Ndabula C., Averik P. D., Jidauna G.G., Abaje I., Oyatayo T. K., and E. O Iguisi, "Analysis of the Spatio-Temporal Dynamics of Landuse/ Landcover Stuctures in the Kaduna Innercore City Region, Nigeria." American Journal of Environmental Protection 1, no. 4 (2013): 112-119. doi: 10.12691/env-14-7.

\section{Introduction}

Urban environment belongs to one of the most dynamic systems on the earth surface due to the heterogeneous nature of urban landuses. The major consequence of this nature of urban landuse dynamics is rapid Landuse/Landcover Changes (LULCC). One the critical concern of the world today is on landuse/landcover changes (LULCC), because of the adverse consequences they have on weather and climate, surface run-off in relation to erosion and flooding, ecological biodiversity, socio-economic and health and the general state of environmental degradation. This is largely because land surface has considerable control on biophysical, biogeophysical, biogeochemical, hydrometeorological, geopedological processes [1,2].
Landuse and Landcover are interrelated concepts but differ to some extents. Landcover refers to the biophysical attributes of the land surface. While, landuse on the other hand refers to the human purpose applied to these biophysical attributes [3,4,5,6]. Changes in landuse or human imprint on the land surface are usually accompanied by a corresponding change in the biophysical environment or landcover. The spatial and temporal dynamics of landuse/landcover is regarded as Landuse/Landcover Change (LULCC). The urban population and socio-economic activities result in the biophysical environment of the once rural region to be replaced with a mosaic of imprints of both cultural and natural features fashioned out by urbanisation processes. Urban areas being a dominant human community cannot function in isolation, economically, socially and physically, but have to be inter-dependent with their immediate rural, agricultural environment for their 
resources and services. It is this encroachment on prime land that causes adverse environmental effects.

The pervasive nature of LULCC is evident when aggregated regionally and globally where they significantly affect primary production and ecosystem services [7], major aspects of earth system function such as biodiversity [8], global climate change [9], and also affect biogeophysical feedback mechanism due to changes in surface albedo and aiding the persistence and occurrence of droughts, desertification and ecological degradation. In a nutshell, LULCC determine in part the vulnerability to climatic, ecologic, economic and sociopolitical perturbations [10]. However, the effects of LULCC at the local or micro scale can be more problematic when related to land degradation issues such as run-off water quality due to sediment and pollution, soil wash and subsequent loss of soil fertility, surface run-off and flooding in addition to loss of environmental resources such as vegetation used directly by the poor. LULCC in an urban environment and its attendant land degradation can increase cost of development and directly affect the urban poor who rely directly on the natural resources around the urban environment for their subsistence.

Common understanding of causes of LULCC is dominated by simplifications which blame LULCC on population and poverty growth, but recent observations showed that human responses to economic opportunities as mediated by institutional factors are the actual drivers of LULCC [11]. Rapid responses to economic opportunities and institutional factors are more pronounced in an urban environment. There is also the need to go beyond the simplification of monitoring and mapping LULCC that has dominated past urban environmental studies, because it is not sufficient to provide the detail understanding of the magnitude of the consequences associated with demographic, socioeconomic and environmental changes following urbanisation. The intensity of urban environmental consequences is a direct function of urban landuse structural changes. Therefore, there is the need to quantitatively analyse using mathematical indexes that will reflect landuse structural changes as well as environmental and socio-economic impacts of LULCC as an index of land degradation.

Kaduna inner core city region is conceptually defined by the Kaduna Master plan [13], as the city’s natural sphere of influence or the area within which its fundamental daily natural resources lie. It is also the area of intensive, daily interaction between the city's population and natural resources and thus functions economically, socially, administratively and control development within the local daily sphere of influence. It was spatially defined to cover twelve (12) miles radius from the center. The inner core of Kaduna city was planned to be largely under urban development with little significance for agriculture, except for the intensive market gardening while the outer core of 35 miles radius is largely for rural agricultural use. These is therefore, a need to carry out a spatio-temporal analysis of the LULC dynamics of the inner core city of Kaduna administrative area in order to understand the nature, structure and composition of Kaduna urban development pattern in the face of the rapidly changing demographic, economic and environmental demands following the reported rapid urban growth of Kaduna metropolis by [14].

Even though, the city was planned, but just as it is common with most developing cities, poor land management has often marred landuse planning with adverse consequences. Urban planning is a continuous process and therefore, requires constant update of spatiotemporal pattern of LULC dynamics for planners, administrators, developers, investors and residents to plan for sustainable development.

Spatio-temporal dynamics of LULCC information is desirable for planning, monitoring management of urban centers at local, regional, national levels. It provides better understanding of land suitability and utilization and thus plays a vital role in the formation of policies, and programs required for development and planning towards sustainable development by checking haphazard development and ensuring that every bit of available urban land is used in the most rational and optimal manner [15].

Therefore, this study is aimed at not just monitoring and mapping LULCC, but in addition, to quantitatively analyse the spatio-temporal dynamics of LULCC structures in Kaduna inner core city environment using mathematical indexes and to explore the driving forces of these LULCC structures to better understand the magnitude of environmental impact caused by such LULCC.

The application of RS/GIS techniques as demonstrated in past studies such as $[16,17,18,19,20]$, have provided improvement in the area of LULCC analysis, which improve environmental management decision to ensure that ecosystems and rapidly changing urban landscapes are suitably matched and managed.

\section{The Study Area}

The study area is located between lat $10^{\circ} 20^{\prime}$ to lat $10^{\circ}$ $40^{\prime}$ and long $7^{\circ} 15^{\prime}$ to $7^{\circ} 35^{\prime}$. The city functions an old regional and present administrative headquarters of Northern Nigeria and Kaduna state respectively. It has also function as industrial center and military garrison. This tri-functional nature of Kaduna and ribbon development along the three major roads in the north, south and west of the city have promoted large unprecedented urban expansion. Major drainage/river systems which play significant physical barrier role in the growth of the city include R. Kaduna, which passes through the city, dividing it into two nearly equal halves, $\mathrm{R}$. Romi with its wide and steep valley in the east and R. Mashi in the west. Large areas of surface rocks and steep gullies have broken the urban built-up into scattered, fragmented and disconnected pattern. The general flattish terrain has encouraged expansion. Climate is characteristically the wet and dry season 'Aw' climate with geology being the basement complex. Vegetation is largely at the transition between southern guinea and northern guinea savanna of Nigeria.

\section{Methodology}

The limits of the inner core region of Kaduna metropolis according to its master plan were sub-setted 
from satellite images using the twelve (12) miles radius in the four corners of the $\mathrm{N}, \mathrm{S}, \mathrm{E}$, and $\mathrm{W}$ dimensions to give a square area rather than the circular area that it represents by definition.

Landuse/ landcover classifications of urban areas have been difficult due to the heterogeneous and small spatial scale of the superficial materials which often lead to higher degree of sub-pixel mixing $[17,21]$. Nevertheless, improved RS/GIS techniques have overcome this problem and hence adopted in this study for landuse/landcover (LULC) classification. A combination of objective and subjective criteria were used with the supervised maximum likelihood classification scheme in preference to the more complex neural networks and fuzzy classification, because it uses the Bayesian coefficient in the maximum likelihood decision rule to minimize the effect of classes that demonstrate high degree of confusion with others within the scene.

To monitor and map LULCC a topomap of 1967 was used as base map representing the $70 \mathrm{~s}$, while the multitemporal satellite images that represented decadal data set series for, 80s, 90s 2000s and 2010s were respectively as follows: LandSat MSS 1987, Spot.XS 1996, NigSat 2006, and Quickbird, 2006. Erdas imagine 8.5 image processing software was used for classification of images.

The base map (topomap of 1967) was digitised to extract built-up layer for the 70s, and was used for georeferencing the satellite imageries which were previously enhanced using, linear contrast stretching method and false colour composite (FCC) to aid image interpretation since vegetation in used as the major index of landcover change that represents the natural or biophysical attribute of land before human urban landuse. The vegetation and landuse map of Nigeria 1993-1995 by FORMECU was used as a guide for image interpretation into different LULC classes. Training using spectral signatures and onscreen digitization was use for extraction of vector layers of the Landsat MSS of 1987 which were later superimposed on respective enhanced FCC images and used to update boundaries of similarly identified LULC classes. Vector layers were edited using Arc info software while LULC map was generated using Erdas lmagine software.

The Normalized Difference Vegetative Index (NDVI) analysis was performed to assess changes in vegetation cover which is use as index of land degradation. NDVI values were scaled and converted to thematic map with similar vegetation classes adopted by FORMECU vegetation map of 1993/95.

A part from monitoring and mapping LULCC, quantitative analysis based on selected mathematical indexes were used, to go beyond the wide simplifications of cause-effect relationship which basically cannot support empirical evidences but have gained more emphasis in most other LULC studies. These indexes are very useful for analysing the spatio-temporal dynamics of LULC and describe the driving force and structure of these LULC which gives better understanding of the level of land degradation due to landuse.

The formulae used for computing the indexes are as follows:

1) Rate of change of LULC $\left(A_{i}\right)$

$$
A_{i}=\frac{U_{b i}-U_{a i}}{\sum\left(U_{b i}-U_{a i}\right)}
$$

Where $A_{i}=$ rate of change of $i^{\text {th }}$ landuse/landcover $U_{a i}=i^{\text {, th }}$ LULC area at beginning of study period $U_{b i}=i^{\text {,th }}$ LULC area at end of study period 2) Landuse/Landcover Change Intensity Index $\left(\mathrm{C}_{\mathrm{i}}\right)$

$$
C_{i}=\frac{U_{b i}-U_{a i}}{B}
$$

Where $i(1,2, \ldots \ldots \ldots, 6)$ no of LULC classes.

$C_{i}=$ LULCC intensity index for $i^{\text {, th }}$ landuse type

$U_{a i}=i^{\text {, th }}$ LULC area at beginning of study period

$U_{b i}=i^{\text {th }}$ LULC area at end of study period

$B=$ Total study Area

3) Landuse/landcover Dynamic Index $\left(D_{i}\right)$

$$
D_{i}=\left(U_{b i}-U_{a i}\right) / U_{a i} \cdot(1 / T) 100 \%
$$

Where $i(1,2, \ldots \ldots \ldots, 6)$

$D_{i}=$ LULC dynamic Index for $i$, th LULC type

$U_{a i}=i^{\text {, th }}$ LULC area at beginning of study period

$U_{b i}=i^{\text {th }}$ LULC area at end of study period

$T=$ Total study period in years.

4) Landuse/Landcover Integrated Index $\left(I_{d}\right)$

$$
I_{d}=100 \times \sum_{i=1}^{6} A_{i} \times C_{i}
$$

where $i$ limits $(100 \ldots . .600)$

$\mathrm{I}_{\mathrm{d}}=$ LULC Intergrated Index

$\mathrm{A}_{i}=$ percentage of $i^{\text {th }}$ level landuse/landcover

$\mathrm{C}_{i}=$ Level of Landuse/landcover

Assignment of $\mathrm{C}_{i}$ level is based on $\mathrm{C} i$ values.

\section{Results Analysis and Discussions}

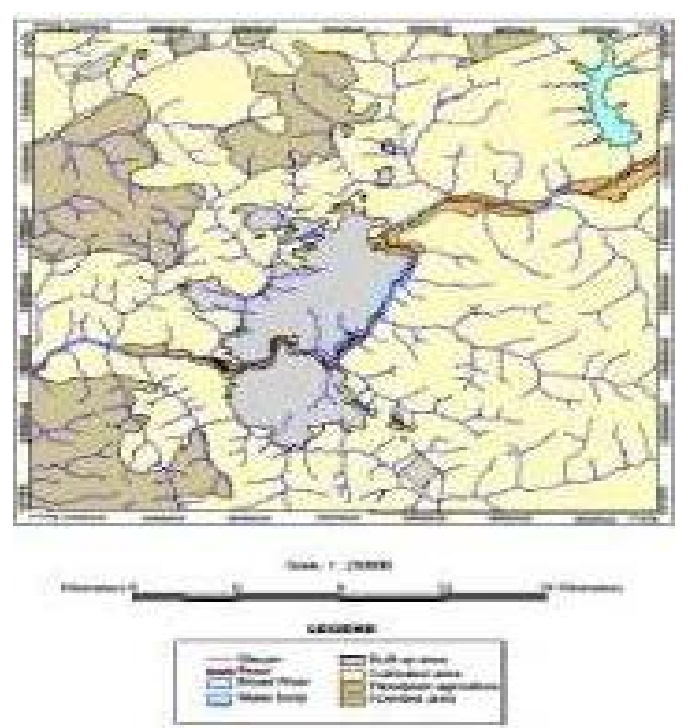

Figure 1. Kaduna Administrative Capital Inner Core Region: Landuse/ Landcover 1980s

The study area was characterized and mapped into six (6) major Landuse/Land cover (LULC) classes and shown to reveal the spatio-temporal patterns of these LULC dynamics as shown in Figure 1, Figure 2, Figure 3, and Figure 4 representing the 1980s, 1990s, 2000s, and 2010s respectively. These changes were estimated and 
summarized in Table 1, the Built-up, Cultivated and Floodplain Agric areas and Broad River showed increasing trend, while Forest and Water bodies showed decreasing trends. The major driving force of these LULC changes is the socio-economic factor of urbanization processes such as population, economic, technological and institutional growth which have triggered competition for space for various urban development purposes such as residential, industrial, commercial, institutional, recreation, transportation thereby increasing built-up, and agriculture to meet up urban food demand resulting in corresponding increase in cultivable land (Figures 1-8). The increase in water bodies is attributed to construction of water reservoirs for water supply and earth dams for irrigation, especially following the state government policy in late 80 s to early 90 s towards agricultural development. The increase in broad river may be associated with seasonal factor at time of capture of data by satellite.

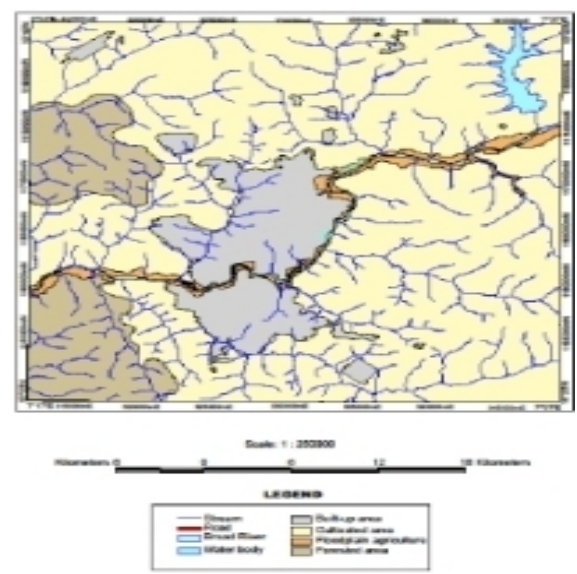

Figure 2. Kaduna Administrative Capital Inner Core Region: Landuse/ Landcover 1990s

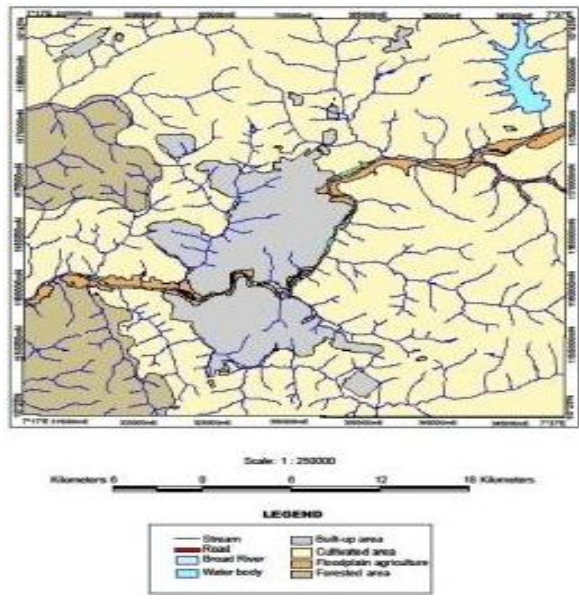

Figure 3. Kaduna Administrative Capital Inner Core Region: Landuse/ Landcover 2000s

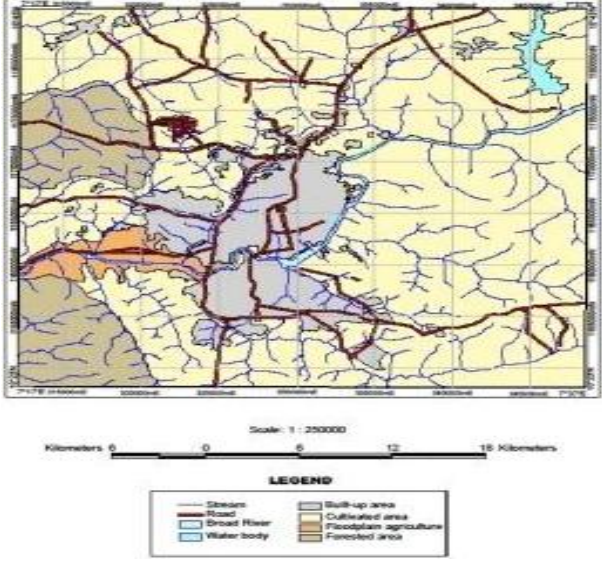

Figure 4. Kaduna Administrative Capital Inner Core Region: Landuse/ Landcover 2010s

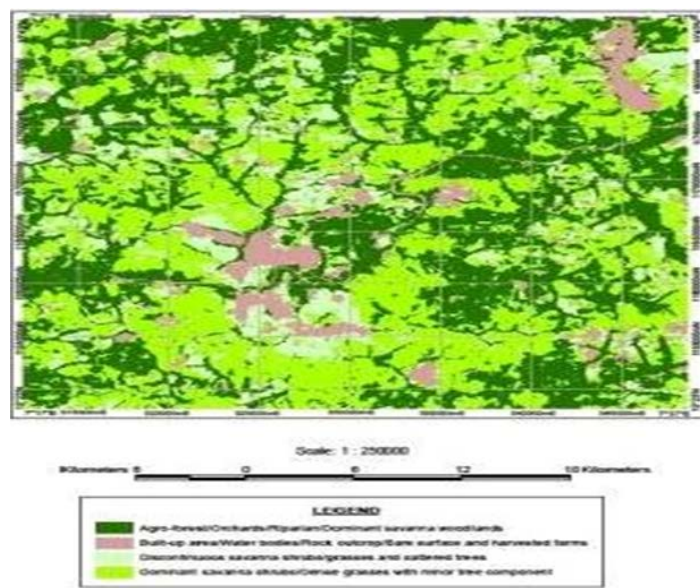

Figure 5. Kaduna Administrative Capital Inner Core Region: Normalized Difference vegetation Index 1980s

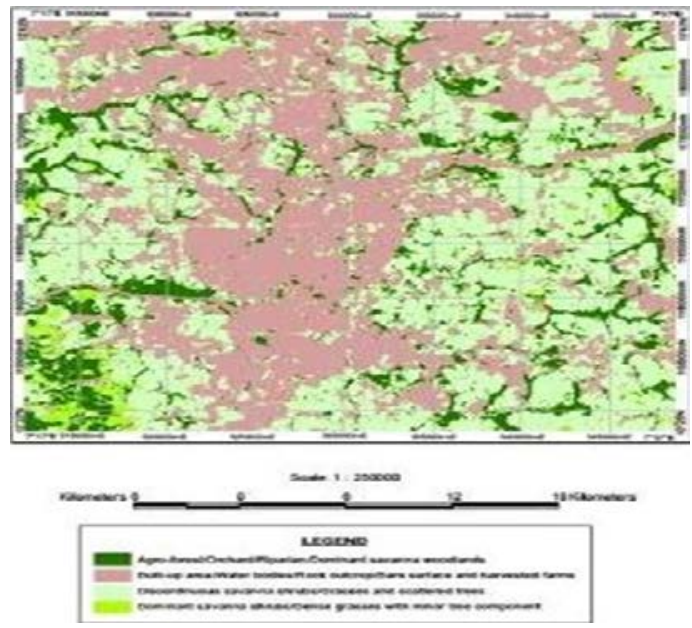

Figure 6. Kaduna Administrative Capital Inner Core Region: Normalized Difference vegetation Index 1990

\begin{tabular}{|c|c|c|c|c|c|c|}
\hline LULC & $\begin{array}{c}\text { Extent in } \mathrm{Km}^{2} \\
1987\left(\mathrm{U}_{\mathrm{ai}}\right)\end{array}$ & $\begin{array}{c}\text { Extent in } \\
\mathrm{Km}^{2} \\
1995\end{array}$ & $\begin{array}{l}\text { Extent in } \\
\mathrm{Km}^{2} 2001\end{array}$ & $\begin{array}{c}\text { Extent in } \\
\mathrm{Km}^{2} 2006 \\
\left(\mathrm{U}_{\mathrm{bi}}\right)\end{array}$ & $\begin{array}{c}\text { Change in Extent in } \mathrm{Km}^{2} \\
1987-2006\left(\mathrm{U}_{\mathrm{bi}}-\mathrm{U}_{\mathrm{ai}}\right)\end{array}$ & $\begin{array}{c}\text { Change in Extent } \\
\text { in \% } \\
(1987-2006)\end{array}$ \\
\hline Built-up Area & 126.13 & 158.96 & 172.47 & 181.01 & 54.88 & 43.51 \\
\hline Cultivated Area & 949.17 & 968.78 & 953.80 & 961.10 & 11.93 & 01.26 \\
\hline Floodplain Agric Area & 25.32 & 32.30 & 31.28 & 34.56 & 9.24 & 36.49 \\
\hline Forest Area & 221.31 & 164.34 & 164.34 & 143.98 & -77.33 & 34.94 \\
\hline Water bodies & 12.38 & 13.03 & 13,03 & 10.97 & -1.16 & 09.37 \\
\hline Broad River & 10.05 & 10.05 & 10.05 & 13.41 & 2.36 & 23.48 \\
\hline Total study Area (B) & 1344.36 & 1347.36 & 1344.94 & 1345.03 & $\sum \mathrm{U}_{\mathrm{bi}}-\mathrm{U}_{\mathrm{ai}}=156.90$ & \\
\hline
\end{tabular}

$\mathrm{B}=\mathrm{Avg}=1346$ 
Linear regression analysis illustrated in Figure 9 and Figure 10 below depict these changing pattern in LULC and a basis for prediction as long as present prevailing factors persist.

The results of indexes shown in Table 2 \& Table 3 below of LULCC showed that Forest area has the highest Landuse Change Intensity Index of about 5.75\% followed by Built-up, 4.08\%. LULC Dynamic Index showed Built- up having the highest of $2.29 \%$ followed by Floodplain Agric and forest areas as $1.92 \%$ and $1.84 \%$ respectively. LULC Integrated Index has shown temporal variations over the years with the highest in 2001 of 539 followed by 2006 of 524 in an upper limit of 600 signifies very high impact of both natural and human factors in the breadth and depth of the study area and thus an indication of degradation of biophysical environment.

Table 2. Summary of Analysis of Landuse/ Land cover Structure Indexes

\begin{tabular}{|c|c|c|c|c|}
\hline LULC & $\mathbf{T}_{\mathrm{i}}(\%)$ & $K_{i}(\%)$ & $\mathbf{A}_{\mathbf{i}}$ & $A_{i}(\%)$ \\
\hline Built-up Area & 4.08 & 2.29 & 0.35 & 35 \\
\hline Cultivated Area & 0.89 & 0.07 & 0.08 & 8 \\
\hline Floodplain Agric Area & 0.69 & 1.92 & 0.06 & 6 \\
\hline Forest Area & 5.75 & -1.84 & 0.49 & 49 \\
\hline Water bodies & 0.09 & -0.49 & 0.01 & 1 \\
\hline Broad River & 0.18 & 1.24 & 0.02 & 2 \\
\hline
\end{tabular}

Table 3. Summary of Analysis of Integrated Landuse Index (Ld) for Different Years

\begin{tabular}{|c|c|c|c|c|c|c|c|c|c|c|c|c|}
\hline \multirow{2}{*}{ LULC } & \multicolumn{4}{|c|}{1995} & \multicolumn{4}{|c|}{2001} & \multicolumn{4}{|c|}{2006} \\
\hline & $\mathbf{A}_{\mathbf{i}}$ & $\mathbf{C}_{\mathbf{i}}$ & $\mathbf{A}_{\mathbf{i}} * \mathbf{C}_{\mathbf{i}}$ & $\mathbf{L}_{\mathbf{d i}}$ & $\mathbf{A}_{\mathbf{i}}$ & $\mathrm{C}_{\mathrm{i}}$ & $\mathbf{A}_{\mathbf{i}} * \mathbf{C}_{\mathbf{i}}$ & $\mathbf{L}_{\mathrm{di}}$ & $\mathbf{A}_{\mathbf{i}}$ & $\mathbf{C}_{\mathbf{i}}$ & $\mathbf{A}_{\mathrm{i}} * \mathbf{C}_{\mathrm{i}}$ & $\mathbf{L}_{\mathrm{di}}$ \\
\hline Cultivated Area & 0.168 & 4 & 0.672 & 67.2 & 0.040 & 3 & 0.120 & 12.0 & 0.080 & 4 & 0.320 & 32.0 \\
\hline Flood Plain Agric Area & 0.060 & 3 & 0.180 & 18.0 & 0.052 & 4 & 0.208 & 20.8 & 0.060 & 3 & 0.180 & 18.0 \\
\hline Water Bodies & 0.006 & 2 & 0.012 & 1.2 & 0.006 & 2 & 0.012 & 1.2 & 0.010 & 1 & 0.010 & 1.0 \\
\hline Broad River & 0.000 & 1 & 0.000 & 0.0 & 0.000 & 1 & 0.000 & 0.0 & 0.020 & 2 & 0.040 & 4.0 \\
\hline $\mathbf{L}_{\mathbf{d}}=100 \sum \mathbf{L}_{\mathbf{d i}}$ & & & & 521 & & & & 539 & & & & 524 \\
\hline
\end{tabular}

Table 4. Summary of Results of Vegetation Cover Changes based on NDVI Analysis (1987-2006)

\begin{tabular}{|c|c|c|c|c|c|}
\hline Vegetation cover class & $\begin{array}{c}\text { Extent in } \\
1987\left(\mathrm{Km}^{2}\right)\end{array}$ & $\begin{array}{c}\text { Extent in } \\
1995\left(\mathrm{Km}^{2}\right)\end{array}$ & $\begin{array}{c}\text { Extent in } \\
2001\left(\mathrm{Km}^{2}\right)\end{array}$ & $\begin{array}{c}\text { Extent in } \\
2005\left(\mathrm{Km}^{2}\right)\end{array}$ & $\begin{array}{l}\text { Change in Extent } \\
1987-2006\left(\mathrm{Km}^{2}\right)\end{array}$ \\
\hline Agroforest/Orchards/Riparian/Dominant savanna woodland & 548.44 & 124.68 & 200.88 & 194.86 & \pm 263.58 \\
\hline Dominant Savanna Shrubs/Minor trees/Dense grasses & 531.56 & 507.48 & 665.59 & 176.5 & \pm 355.06 \\
\hline Discontinuous Savanna Shrubs/Grasses & 261.01 & 533.97 & 320.32 & 488.07 & \pm 227.06 \\
\hline
\end{tabular}

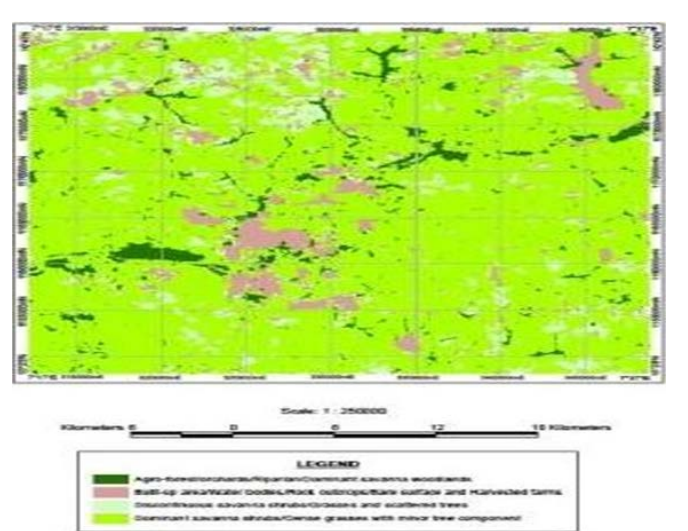

Figure 7. Kaduna Administrative Capital Inner Core Region: Normalized Difference vegetation Index 2000s

NDVI analysis results showed changes in quantity of vegetation among the different categories of vegetation in both space and time as shown in Figure 5, Figure 6, Figure 7, and Figure 8 representing 1980s, 1990s, 2000s and 2010 s in a decadal series. The changes in vegetation quantity were estimated and summarized in Table 4 below. Results revealed severe deforestation in the Agro forest/Riparian/Dominant savanna woodland and the Dominant savanna shrubs vegetation which declined by about 263.58 and $355.06 \mathrm{Km}^{2}$ extents respectively between 1987-2006, leaving most of the metropolitan environment to Discontinuous Savanna and non-vegetated surfaces which increased by 227.06 and $472.65 \mathrm{Km}^{2}$ extents respectively. Both natural and socio-economic factors can be blamed as drivers of degradation of vegetation cover, for instance, the persistent droughts in the Sudano-sahelian zone of Nigeria as recorded in 1973, 1983 and 1993 droughts as reported by [22,23] in addition to bush fire are likely factors for declining vegetation. Besides the rapid increase in the total population, there has 
been a rapid rate of urbanization over the years. It is believed that the rate of urbanization is between 5 and $10 \%$ [24]. The main reason for the rapid rate of urbanization is the creation of more growth poles through the creation of more states and local government areas. The provision of infrastructure at the headquarters usually aggravates the inequality between the rural land poles, leading to increased rural-urban migration. Rapid urbanization results in rapid construction and clearance of vegetation within and outside the urban centres to satisfy the needs of the urban people as well as urban congestion. The rapid population growth and urbanization described earlier have fueled a rapid economic development in Nigeria and Kaduna metropolis in particular. The interaction of these phenomena leads, on a positive note, to the expansion of agriculture and changes in the agriculture practiced. However, when the increased population and its demands are pitched against dwindling resources of government and worse still at the background of inappropriate economic policies of the government such as the Structural Adjustment Programme (SAP) of the President Babangida administration in the late 80s and early 90s which greatly impoverished rural dwellers to accelerate rural-urban migration and urban dwellers who complimented their poor earnings with subsistence farming at the urban fringes and coupled with the energy crisis in the past 3 decades which both rural and urban population responded by alternative fuel wood dealt a great blow in deforestation in the Kaduna inner core city region. Increase grazing in the buffer Sudan vegetation belt following southward shift of the Sahel is also contending factor of deforestation in this zone [24].

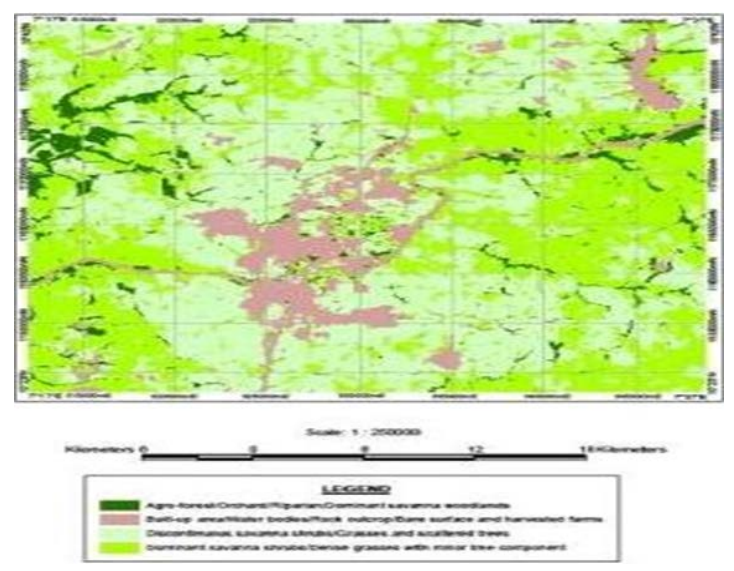

Figure 8. Kaduna Administrative Capital Inner Core Region: Normalized Difference vegetation Index 2010s

Figure 11 illustrates the linear regression model and trends in vegetation cover changes.

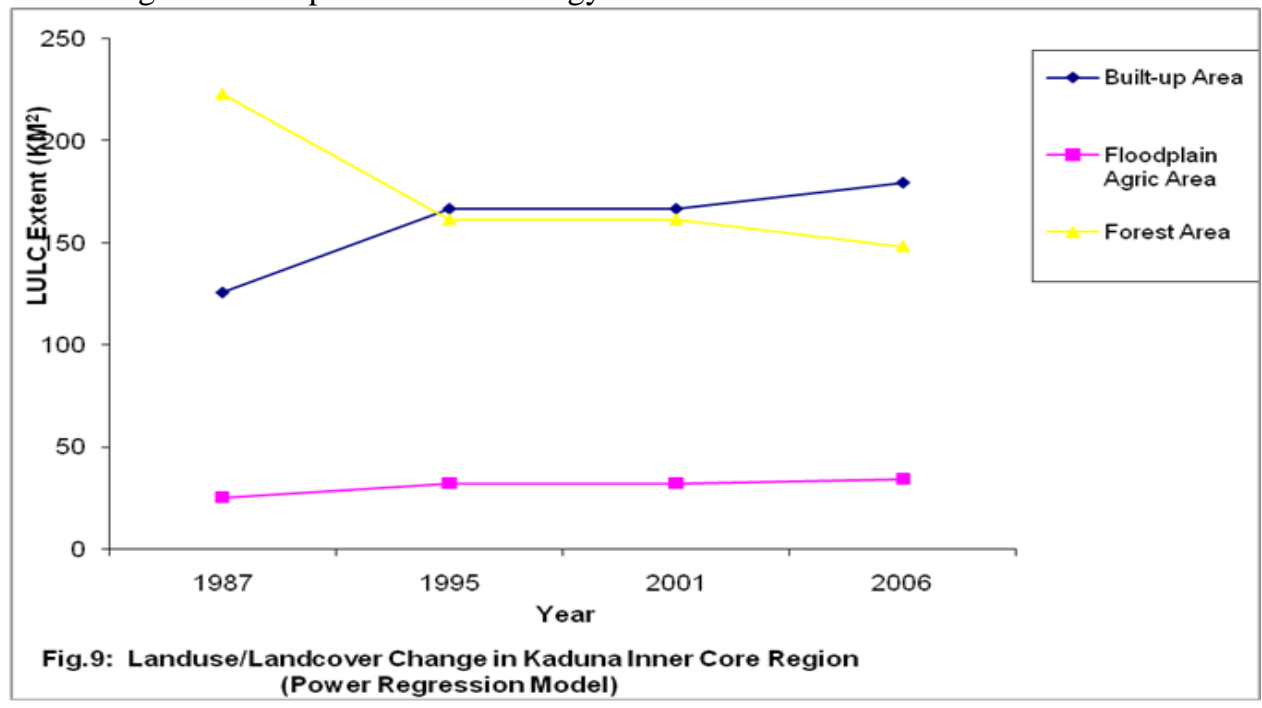

Figure 9. Landuse/ Landcover Chang in Kaduna Inner Core Region (Power Regression Model)

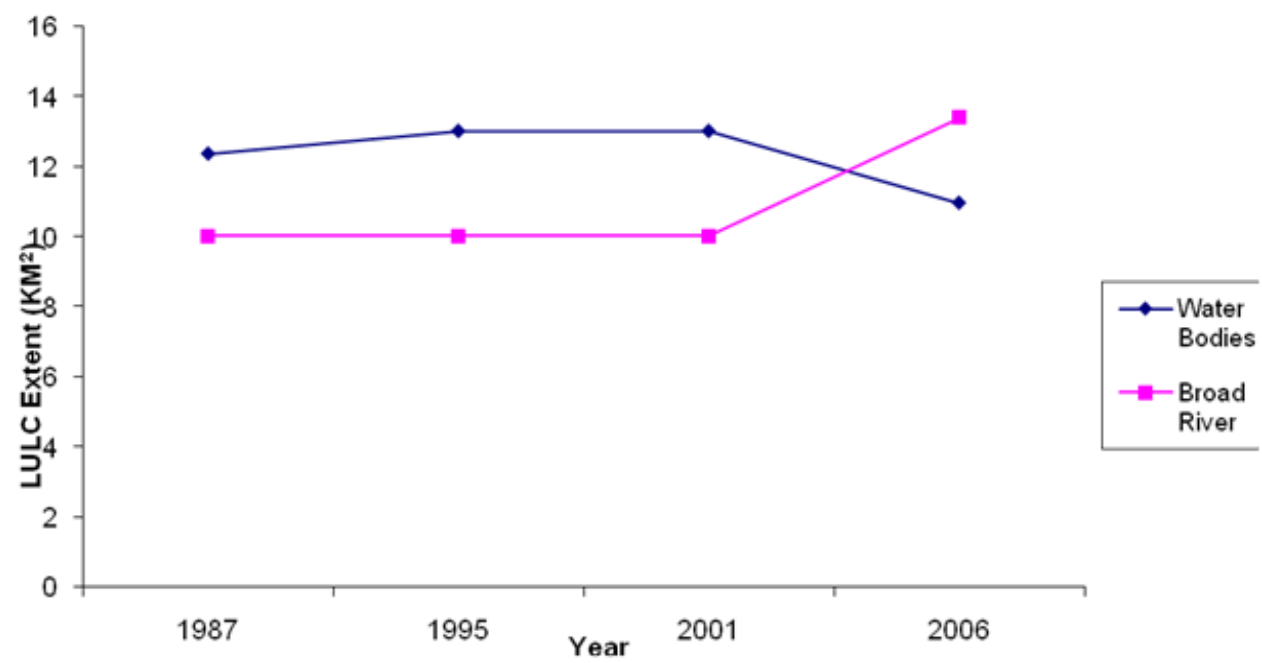

Figure 10. Landuse/Landcover Changes in Kaduna Inner Core City Region (Quadratic Regression Model) 

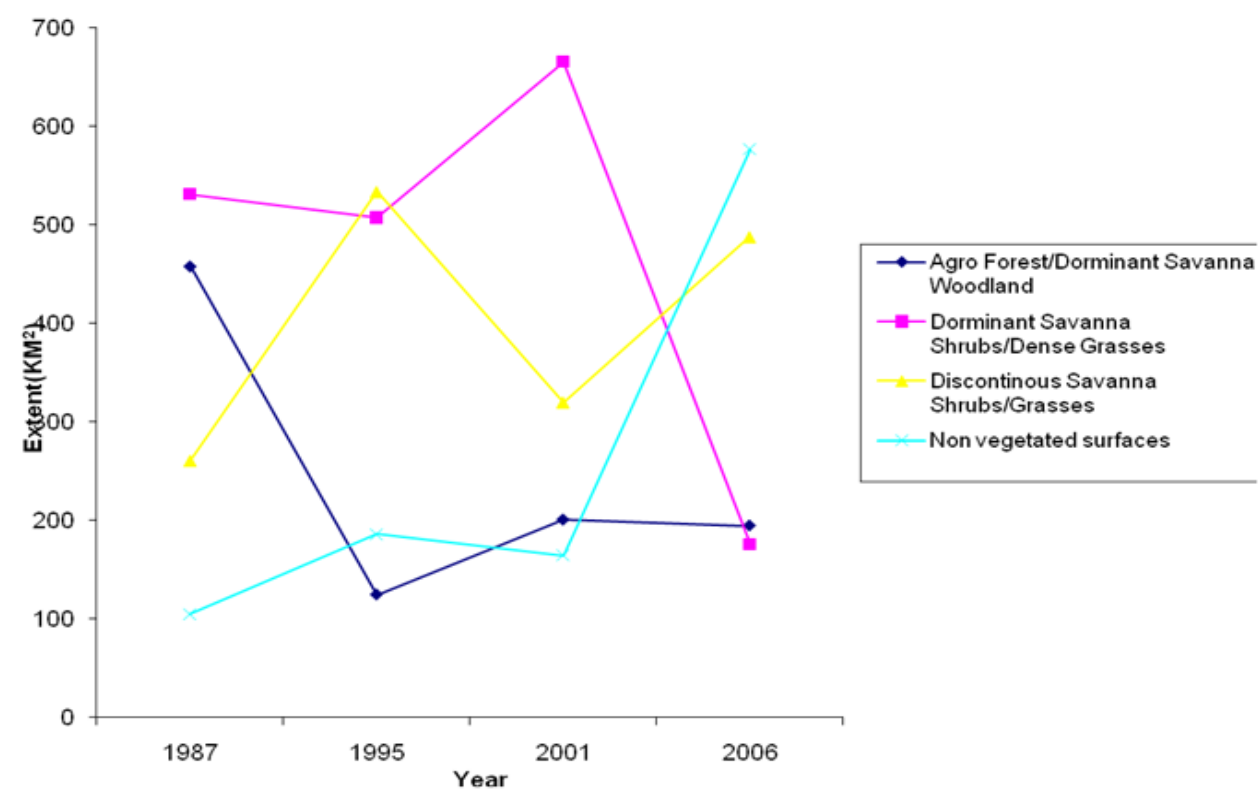

Figure 11. Vegetation Cover Changes in Kaduna Inner Core City Region

\section{Conclusion and Recommendations}

This study has proven that urbanization processes are often accompanied by rapid spatio-temporal LULC dynamics, especially in rapid urbanizing developing cities like Kaduna metropolis in Nigeria despite proposed planning, due to compelling socio-economic factors such as rapid urban population and economic growth in the face of inappropriate economic policies, weak institutional urban planning and monitoring mechanisms, energy crisis and the deepening of urban poverty, forcing urban dwellers to respond to natural resources such as land, vegetation in an unfriendly environmental manner. The monitoring and quantification of LULCC using Indexes; NDVI, Change Intensity Index $\left(\mathrm{T}_{\mathrm{i}}\right)$, Dynamic Index $\left(\mathrm{K}_{\mathrm{i}}\right)$ and Integrated Index provided a better basis for spatiotemporal analysis of LULCC and better explanation to the driving forces of these LULCC. These indices critically analyse the quantity, rate, as well as the magnitude of change among various LULC in the study area, which provides a basis for comparisons with other places to better explain the spatio-temporal dynamics of LULC as an Index of land degradation, since these indices best account for biophysical and socio-economic factors of LULCC which differ due to natural, economic and social factors from place to place. These further suggest the need for integrated landuse planning based on natural, economic, social and other factors in the urban environment. Rational and sustainable use of land in time and space should not be compromised for whatever short terms gains. The ecological biomes of Dominant Savanna Woodland and Shrubs, Riparian and Agro-forest should be protected from cultivation and fuel wood depletion. The attainment of both economic and environmental development goals by municipal or state government remain intricately bound and vicious. There is a serious need for addressing urban poverty through sustainable economic development projects. This will compliment the vulnerability of institutional frameworks and facilitate enforcement regulations towards planning.

\section{References}

[1] S.M. Abubakar, Y.R. Kudanmiya, and P.N. Eyongs, Assessing of Environmental Degradation Using Satellite Remote Sensing Technologies in Talata Mafara Area, Northern Nigeria. Environmental Review 4(2002), No 1, pp 577-586.

[2] United States Climate Change Science Programme (US CCSP), Landuse/Landcover Changes. Final Report on Strategic Plan for Climate Change Science Programme, 2004. Available online at: www.climatescience.gov.

[3] B.L. Turner, W.C. Clark, R.W. Kates, J.F. Richards, J.T. Mathew, W.B. Meyer, (Eds) The Earth as Tranformed by Human Action. Global and Regional changes in the Biosphere over the past 300 years, Cambridge University press, Cambridge, 1990.

[4] B.I. Turner, R.H. Moss, and D.L. Skole, (Eds) Relating Landuse and Global Landuse Change: A Proposal for an IGBP-HDP Core Project IGBP Report, 1993, NO. 5 p 95.

[5] E.F. Lambin, et'al Landuse and Landcover Change: Implementation Strategy. IGBP Report No 48, IHDP Report No 10, Stockholm, Bonn, 1999.

[6] E.F. Lambin, et'al, The Causes of Landuse and Landcover Change: Moving Beyond the Myths, Global Environmental Change 11 (2001) 261-269.

[7] E. Lopez, G. Bocco, M. Mendozoa, and E. Duhau, E, Predicting Landcover/Landuse Change in the Urban Fringe. A case in Morelia City, Mexico. Landscape and Urban Planning 55(2001), pp 271-285.

[8] T.N. Chase, R.A. Pielke, T.G.F. Kittel, R.R. Nemani, S.W. Running, Simulated Impacts of Historical Landcover Changes on Global Climate in Northern winter. Climate Dynamics 16(1999) 93-105.

[9] P.M. Vitousek, H.A. Mooney, J. Lubchrenco, J.M. Melilo, Human Domination of Earth's Ecosystems. Science (277), 1997, pp 494499.

[10] J.X. Kasperson, R.E. Kasperson, B.L. II Turner, (Eds), Regions at Risk; Comparisons of Threatened Environments. United Nations University, Press, Tokyo, 1995.

[11] Y. Wang, A typical Agricultural Areas of China-Dzeou city's Land Use Structure Changes based on a Past Decade Data. Journal of Geography and Geology Vol. 2, No 1, P93-97, 2010.

[12] W. Wang,Yu. cheng, Li. Gang, C. Zhang, N. Junsheng, Studies on Landuse/Landcover Change with Integration of RS, GIS and GPS Technologies: The Case of Baotou City in Ecotonec of Agriculture-animal Husbandry, China, 2004. Available online at: Liglzu@gmail.com.

[13] Kaduna Replanned Master Plan, Inner Core City Region, 1990, PP. 22. 
[14] C. Ndabula, Assessment of Land use/ Land cover changes in Kaduna Metropolitan Area. Unpublished M,Sc ,Thesis,2005, Department of Geography, ABU Zaria.

[15] R.B.D. Gupta, S.K. Srivastava, Monitoring of change in landuse/landcoever using multi-sensor satellite data. National Institute of technology Allahabad India, 2004. available online at: Gupta rd@ rediffmail.com.

[16] X. Yang, and C.P. LO, (2003) Modeling Urban Growth and Landscape Changes in the Atlanta Metropolitan Area. International Journal of Geographical Information Systems. Vol. 17(5) pp 463-488, 2003.

[17] R.O. Oyinloye, B.F. Abgo, and Z.O. Aliyu, Application of Nigerian Sat1 Data for Landuse/Landcover Change Mapping. National Space Research and Development Agency NASRDA News Vol. 7, Issue , 3, 2002, Pp 20-24.

[18] M.S. Ramsey, W.L. Stefanov, and P.R. Christensen, Monitoring World-wide Urban Landcover Changes Using ASTER. In: Proceedings of the $13^{\text {th }}$ International Conference, Applied Geological Remote Sensing Michigan (2), 1998, PP 237-244.
[19] K.S. Rajan, A New Concept in Modeling Landuse/Landcover. In proceedings of the $19^{\text {th }}$ Asian conference on Remote sensing. Ruklanthi,S., (1996) Monitoring Landuse Changes in Sri- Lanka. In proceedings of the $17^{\text {th }}$ Asian conference on Remote sensing, 1998.

[20] W.T.G. Medis, and A. Wadigamangawa, Integration of Remote Sensing and GIS for Landuse/Landcover Mapping in Nil Wala Basin. In proceedings of the $17^{\text {th }}$ Asia conference on Remote sensing, Paul Suharto, Indonesia, 1996.

[21] G.M. Foody, and R.M. Embashi, Mapping Despoiled Landcover from Landsat. Mapper Imageing (2000), available online at:http://mw.sciencedirect.com.

[22] D.O. Adefolalu, Rainfall Trends in Nigeria, Theoritical and Applied Climatology (37), 1986, pp205-209.

[23] E.O. Oladipo, A Comprehensive Approach to Drought and Desertification in Northern Nigeria, Natural Hazards (8), 1993, pp171-188.

[24] Federal Ministry of Environment (FME), Report on National Action Programme to Combat Desertification (NAPCD), 2010, pp. 6-8. 